\title{
Effects of Restricted Feeding on the Absorption, Metabolism, and Accumulation of Pentachlorobenzene in Rats
}

\author{
Keizo Umegaki, Sachie Ikegami, and Tomio IchIKawa \\ The National Institute of Health and Nutrition, \\ Toyama, Shinjuku-ku, Tokyo 162, Japan
}

(Received June 29, 1992)

\begin{abstract}
Summary To investigate the effect of restricted feeding (RF) on the absorption, metabolism, and accumulation of pentachlorobenzene (PECB), rats were fed either ad libitum (AD) or a restricted diet (at 25 or $50 \%$ of AD) for 15 days. On the 7 th day (day 0$)$, PECB $(15 \mathrm{mg} / \mathrm{rat})$ was orally administered. Daily fecal weight and the total amount of PECB excreted into feces were decreased by RF, indicating an increase in PECB absorption due to its prolonged retention in the gastrointestinal tract. However, the amount of PECB excreted was only $4.8 \%$ of the dose given to the AD group, and 2.1 and $2.4 \%$ of that given to the 50 and $25 \%$ restricted diet groups, respectively. The concentrations of PECB and pentachlorophenol, and major metabolite, in blood of the restricted diet groups were higher on day 2 and day 4, while lower on day 6 and day 8 than those of the AD group. On day 8, PECB in liver, kidney, brain, and fat tissue were also lower in the restricted diet groups; the PECB levels in such tissue in the 25 and 50\% restricted diet groups were $10-40$ and 5-11\% of that in the $\mathrm{AD}$ group, respectively. These results indicate that PECB metabolism was increased by RF. As PECB is lipophilic, it is most likely that the fat tissue mass, which was markedly decreased by RF, contributed to the enhancement of PECB metabolism. The mechanism seemed to be as follows: as fat tissue mass accumulating PECB decreased, the concentration of PECB in the liver increased, thus the amount of PECB metabolites formed was increased.
\end{abstract}

Key Words pentachlorobenzene, absorption, accumulation, metabolism, fat tissue, food restriction, rat, pentachlorophenol

Various organochlorine chemicals are present in the environment such as pesticides, herbicides, and intermediate products. These chemicals are lipophilic and tend to accumulate in fat tissue for a long time without being metabolized. The mobilization of such a chemical from the fat tissue into the blood is an important step toward its metabolism in the liver and its excretion from the body. Restricted feeding (RF) and fasting lead to decreased fat tissue mass, thereby mobilizing the chemical from the fat tissue together with lipolysis and enhancing its metabolism 
in the liver. In addition, it has been reported that RF treatment influences the activity of the hepatic drug-metabolizing enzymes $(1,2)$.

The effects of RF on the excretion of DDT $(3,4)$, hexachlorobenzene $(5,6)$, and hexachlorobiphenyl $(7,8)$ have been tested. However, the results of these reports are inconsistent. In some cases, RF effectively enhanced chemical metabolism and excretion, but in other cases the treatment led to the redistribution of the chemicals, especially from fat tissue to the brain, and increased their toxicity. In most of these studies, the effect of RF was examined after the administration of the chemicals. RF prior to the administration of the chemicals might greatly influence both the transit time of the chemicals and fat tissue mass. The transit time might affect the absorption of the chemicals in the gastrointestinal tract, and the fat tissue mass might affect the distribution of the chemicals in the body. In many reports fat tissue has been recognized as a deposition site of lipophilic chemicals. Reports concerning the influence of fat tissue on the metabolism of these chemicals are scarce.

Using pentachlorobenzene (PECB) which is lipophilic and relatively metabolizable, we have observed that both metabolism and excretion of PECB were markedly greater in young rats than in adult rats, and that its mechanism was associated with the difference of fat tissue mass $(9)$. That report demonstrated that a smaller fat tissue mass enhanced the concentration of PECB in the liver, resulting in an enhancement of its metabolism through hepatic drug-metabolizing enzymes. In this report, rats were fed restricted diets one week prior to the administration of PECB, and the influence of RF on the absorption, metabolism, and accumulation of PECB was examined. The results indicate that RF increases the absorption of PECB, whereas it accelerates the metabolism of PECB by affecting the availability of the chemical to hepatic drug-metabolizing enzymes, and markedly decreases PECB residues in various tissues.

\section{MATERIALS AND METHODS}

1) Materials. PECB, pentachlorophenol (PCP), 2-aminophenol were purchased from Tokyo Kasei Kogyo Co., and UDP-glucuronic acid was obtained from Seikagaku Kogyo Co. Other chemicals were purchased from Wako Pure Chemical Industries. PECB was recrystallized 3 times from methanol before use.

2) Experimental animals. Male Wistar rats (6 weeks of age) obtained from Japan Clea, Tokyo, were divided into three dietary groups of 12 rats each: ad libitum (AD) group: $25 \%$ restricted diet group which was fed $75 \%$ that of the AD group; $50 \%$ restricted diet group which was fed $50 \%$ that of the AD group. The food (CE-2, Japan Clea) consumption of the AD group was measured daily and feeding in the 25 and $50 \%$ restricted diet groups was reduced to 75 and $50 \%$, respectively, of the average food consumption of the AD group. Rats were maintained on these dietary conditions throughout the 15 days of the experimental period in metabolic cages. After one week, each group was further divided into two groups of 6 rats each: PECB-treated and untreated. PECB-treated rats received by intragastric 
gavage a single dose of PECB $(15 \mathrm{mg})$ dissolved in $0.5 \mathrm{ml}$ of soybean oil and untreated rats received an equal volume of soybean oil. The dose is not toxic as assessed from serum transaminase activities (10). For the analysis of PECB and its metabolites, blood $(0.01-0.05 \mathrm{ml})$ was taken from the tail vein, and urine and feces were collected daily. After overnight fasting, rats were anesthetized with ether, and sacrificed by an incision to the abdominal aorta.

3) Measurement of enzyme activity and glutathione. The liver was rinsed with $0.9 \% \mathrm{NaCl}$ solution, weighed and homogenized with $50 \mathrm{~mm}$ Tris- $\mathrm{HCl}$ buffer (pH 7.4) containing $0.25 \mathrm{M}$ sucrose. The homogenate was centrifuged at $10,000 \times g$ at $4^{\circ} \mathrm{C}$ for $30 \mathrm{~min}$ and the supernatant was further centrifuged at $105,000 \times g$ at $4^{\circ} \mathrm{C}$ for $60 \mathrm{~min}$. The supernatant and the pellet were used as the cytosol fraction and the microsomal fraction, respectively. The microsomal fraction was resuspended in $50 \mathrm{~mm}$ Tris- $\mathrm{HCl}$ buffer $(\mathrm{pH} 7.4)$. For measurement of cytochrome P-450 content, the pellet was washed with $0.1 \mathrm{M}$ phosphate buffer $(\mathrm{pH} 7.4)$ and finally resuspended in $0.1 \mathrm{M}$ phosphate buffer $(\mathrm{pH} 7.4)$ containing $20 \%$ glycerol. Cytochrome P-450 content was measured by the method of Omura and Sato(11). UDPglucuronyltransferase activity in the microsomal fraction was determined by the method of Dutton et al.(12) using 2-aminophenol as a substrate. Glutathione $S$-transferase activity in the cytosol fraction was measured by the method of Habig and Jakoby (13) using 1-chloro-2,4-dinitrobenzene as a substrate. Protein and glutathione levels were determined according to the method of Lowry et al. (14) and Mokrasch and Teschke(15), respectively. Serum transaminase (GPT) activity was assayed using diagnostic kits purchased from Wako Pure Chemical Industries.

4) Measurement of PECB and PCP. Tissues were homogenized with four volumes of distilled water. Blood $(0.01-0.2 \mathrm{ml})$ was mixed with $0.8-0.99 \mathrm{ml}$ of distilled water. Feces were dried, weighed, and pulverized. PECB in the samples was extracted with $n$-hexane. PCP in the samples was extracted with ethylacetate and methylated with an ethereal solution of diazomethane. PECB and PCP were analyzed on a Hitachi 663-30 gas chromatograph with an electron capture detector as described elsewhere (16).

5) Statistical analysis. Data were calculated as mean \pm SEM. Comparison between groups was made by one-way analysis of variance followed by Duncan's multiple range test.

\section{RESULTS}

RF significantly attenuated the increase in body weight (Fig. 1). In the $50 \%$ restricted diet group, neither increase nor decrease of the body weight was observed. Body weight was decreased by overnight fasting before sacrifice was performed in the $\mathrm{AD}$ and $25 \%$ restricted diet groups. The ratio of liver weight to body weight was not different among the three groups. On the other hand, the ratio of fat tissue weight to body weight significantly decreased as the diet restriction rate increased (Table 1). A marked change was observed especially in tissue weight of perirenal 


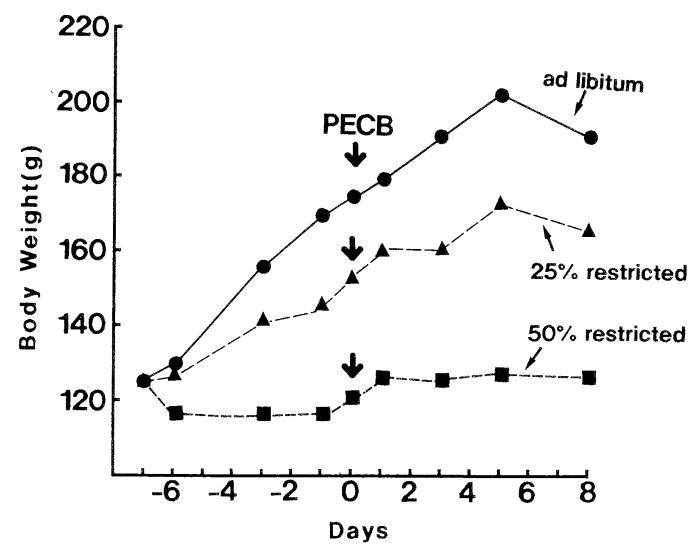

Fig. 1. Changes in body weight. Rats were fed either ad libitum (AD) or a restricted diet (at 25 or $50 \%$ ) for 15 days. On the 7th day (day 0), $15 \mathrm{mg}$ of PECB was orally administered per rat. Each point indicates mean for 5-6 rats.

Table 1. Body weight and tissue weight.

\begin{tabular}{cccc}
\hline & Ad libitum & $25 \%$ restricted diet & $50 \%$ restricted diet \\
\hline Body weight $(\mathrm{g})$ & $194 \pm 6.65[100]^{\mathrm{a}}$ & $159 \pm 3.33[82]^{\mathrm{b}}$ & $130 \pm 4.08[67]^{\mathrm{c}}$ \\
$\quad$ gain (g) & $68.7 \pm 2.72[100]^{\mathrm{a}}$ & $34.3 \pm 1.36[50]^{\mathrm{b}}$ & $4.67 \pm 1.67[7]^{\mathrm{c}}$ \\
Tissue weight & & & \\
$(\%$ of body weight) & & & \\
Liver & $3.34 \pm 0.157[100]$ & $3.75 \pm 0.072[112]$ & $3.53 \pm 0.129[106]$ \\
$\quad$ Epididymal fat & $0.88 \pm 0.114[100]^{\mathrm{a}}$ & $0.78 \pm 0.070[87]^{\mathrm{a}}$ & $0.58 \pm 0.032[66]^{\mathrm{b}}$ \\
$\quad$ Perirenal fat & $0.90 \pm 0.168[100]^{\mathrm{a}}$ & $0.60 \pm 0.200[67]^{\mathrm{b}}$ & $0.24 \pm 0.054[27]^{\mathrm{c}}$ \\
\hline
\end{tabular}

Mean \pm SD for 5-6 rats. ${ }^{\#}$ Body weight gain during experimental period (day 7 to day $8)$. Values with different superscripts in the same line are significantly different from one another $(p<0.05)$. Numbers within brackets indicate $\%$ of ad libitum values.

fat both in the 25 and $50 \%$ restricted diet groups. These decreases of the fat tissue weight by RF were almost the same as those found in a previously reported study of RF treatment for one week (17). This suggests that the fat tissue mass had already markedly been reduced through RF by the time PECB was administered (day 0). None of the groups exhibited any changes of body weight, tissue weight or serum GPT activity due to PECB administration (data not shown).

Although fecal excretion of PECB was greatest during days 0-1 regardless of the feeding condition, the amounts of PECB excreted in the 25 and $50 \%$ restricted diet groups were smaller during days $0-1$ and days $3-8$, but greater during days 1-2 compared with the corresponding findings of the AD group (Table 2). Although the cumulative fecal excretion of PECB during the experimental period was significantly decreased by the RF, the amounts were only $4.8 \%$ of the dose in the 
Table 2. Fecal excretion of PECB through time.

\begin{tabular}{rccc}
\hline \multirow{3}{*}{$\begin{array}{c}\text { Time } \\
\text { (day) }\end{array}$} & PECB in feces $(\mu \mathrm{g})$ \\
\cline { 2 - 4 } & Ad libitum & $25 \%$ restricted diet & $50 \%$ restricted diet \\
\hline $0-1$ & $642 \pm 77.2[100]^{\mathrm{a}}$ & $228 \pm 73.1[36]^{\mathrm{b}}$ & $179 \pm 46.2[29]^{\mathrm{b}}$ \\
$1-2$ & $46.2 \pm 5.16[100]^{\mathrm{a}}$ & $95.6 \pm 20.2[207]^{\mathrm{ab}}$ & $110 \pm 17.9[238]^{\mathrm{b}}$ \\
$2-3$ & $21.4 \pm 1.34[100]$ & $21.3 \pm 3.21[99]$ & $18.5 \pm 1.02[86]$ \\
$3-4$ & $11.8 \pm 2.86[100]^{\mathrm{a}}$ & $9.77 \pm 1.85[83]^{\mathrm{ab}}$ & $4.30 \pm 0.83[36]^{\mathrm{b}}$ \\
$4-8$ & $3.74 \pm 0.75[100]^{\mathrm{a}}$ & $2.36 \pm 0.47[63]^{\mathrm{ab}}$ & $1.54 \pm 0.28[41]^{\mathrm{b}}$ \\
Total & $725 \pm 69.6[100]^{\mathrm{a}}$ & $357 \pm 71.5[50]^{\mathrm{b}}$ & $313 \pm 46.1[44]^{\mathrm{b}}$ \\
$0-8$ & & & \\
\hline
\end{tabular}

Mean \pm SE for 5-6 rats. Values with different superscripts in the same line are significantly different from one another $(p<0.05)$. Numbers within brackets indicate $\%$ of ad libitum values.

Table 3. PECB concentration in the blood through time.

\begin{tabular}{|c|c|c|c|}
\hline \multirow{2}{*}{ Time } & \multicolumn{3}{|c|}{ PECB in blood $(\mathrm{ng} / \mathrm{ml})$} \\
\hline & Ad libitum & $25 \%$ restricted diet & $50 \%$ restricted diet \\
\hline $3 \mathrm{~h}$ & $5,793 \pm 1,034[100]$ & $7,638 \pm 863 \quad[132]$ & $5,078 \pm 1,321[88]$ \\
\hline $7 \mathrm{~h}$ & $5,193 \pm 698 \quad[100]^{\mathrm{a}}$ & $9,742 \pm 1,475[188]^{\mathrm{b}}$ & $8,408 \pm 1,033[162]^{\mathrm{b}}$ \\
\hline Day 1 & $1,358 \pm 77.6 \quad[100]^{\mathrm{a}}$ & $2,000 \pm 162 \quad[147]^{\mathrm{b}}$ & $3,995 \pm 280 \quad[294]^{\mathrm{c}}$ \\
\hline Day 2 & $705 \pm 63.1 \quad[100]^{\mathrm{a}}$ & $932 \pm 101 \quad[130]^{\mathrm{ab}}$ & $1,000 \pm 53.9 \quad[140]^{\mathrm{b}}$ \\
\hline Day 4 & $230 \pm 36.3[100]^{\mathrm{a}}$ & $121 \pm 30.5 \quad[52]^{\mathrm{b}}$ & $56.9 \pm 13.0[24]^{\mathrm{b}}$ \\
\hline Day 6 & $63.3 \pm 8.54 \quad[100]^{\mathrm{a}}$ & $25.2 \pm 4.19 \quad[40]^{\mathrm{b}}$ & $6.89 \pm 1.32[11]^{\mathrm{c}}$ \\
\hline Day 8 & $9.05 \pm 1.05 \quad[100]^{\mathrm{a}}$ & $3.27 \pm 0.30 \quad[41]^{\mathrm{b}}$ & $2.57 \pm 0.389[28]^{\mathrm{b}}$ \\
\hline
\end{tabular}

Mean \pm SE for $5-6$ rats. Values with different superscripts in the same line are significantly different from one another $(p<0.05)$. Numbers within brackets indicate $\%$ of ad libitum values.

AD group, and 2.4 and $2.1 \%$ in the 25 and $50 \%$ restricted diet groups, respectively. These differences in fecal PECB excretion were associated with the differences in daily fecal weight due to RF. The average daily fecal weights were $6.1 \mathrm{~g}$ in the AD group, and 4.5 and $3.0 \mathrm{~g}$ in the 25 and $50 \%$ restricted diet groups, respectively.

The time course changes of PECB concentration in blood are shown in Table 3 . In the restricted diet groups, PECB concentration in the blood was higher until day 2 and lower after day 4 than that in the AD group. The calculated half-lives for PECB were $24 \mathrm{~h}$ in the AD group, and 18 and $15 \mathrm{~h}$ in the 25 and $50 \%$ restricted diet groups, respectively. The amount of PECB residues in the liver, kidney, brain, and fat tissues on day 8 in the restricted diet groups was significantly lower than that in the AD group (Table 4). 
Table 4. PECB levels in various tissues.

\begin{tabular}{|c|c|c|c|}
\hline & Ad libitum & $25 \%$ restricted diet & $50 \%$ restricted diet \\
\hline \multicolumn{4}{|l|}{ Liver } \\
\hline$(\mathrm{ng} / \mathrm{g})$ & $23.5 \pm 2.79[100]^{\mathrm{a}}$ & $6.50 \pm 0.97[28]^{\mathrm{b}}$ & $2.26 \pm 0.64[10]^{\mathrm{b}}$ \\
\hline (ng/tissue) & $160 \pm 19.4[100]^{\mathrm{a}}$ & $37.0 \pm 5.65[23]^{\mathrm{b}}$ & $14.9 \pm 4.04[9]^{\mathrm{b}}$ \\
\hline \multicolumn{4}{|l|}{ Kidney } \\
\hline $\begin{array}{l}\text { (ng/g) } \\
\text { Brain }\end{array}$ & $71.6 \pm 9.99[100]^{\mathrm{a}}$ & $20.0 \pm 2.07[28]^{\mathrm{b}}$ & $7.44 \pm 1.38[10]^{\mathrm{b}}$ \\
\hline Fat ${ }^{(n g / g)}$ & $32.5 \pm 5.08[100]^{\mathrm{a}}$ & $12.9 \pm 1.47[40]^{\mathrm{b}}$ & $2.80 \pm 0.62[9]^{\mathrm{b}}$ \\
\hline $\begin{array}{l}\text { Epididymal } \\
\text { (ng/g) } \\
\text { (ng/tissue) }\end{array}$ & $\begin{array}{l}1,253 \pm 214 \quad[100]^{\mathrm{a}} \\
2,156+416[100]^{\mathrm{a}}\end{array}$ & $\begin{array}{l}258 \pm 18.1[21]^{\mathrm{b}} \\
314+26.5[16]^{\mathrm{b}}\end{array}$ & $\begin{array}{l}141 \pm 23.2[11]^{\mathrm{b}} \\
106+17.5[5]^{\mathrm{b}}\end{array}$ \\
\hline $\begin{array}{l}\text { Perirenal } \\
\quad \text { (ng/g) } \\
\text { (ng/tissue) }\end{array}$ & $\begin{array}{r}657 \pm 181 \quad[100]^{\mathrm{a}} \\
1,430 \pm 408 \quad[100]^{\mathrm{a}}\end{array}$ & $\begin{array}{l}136 \pm 25.0[20]^{\mathrm{b}} \\
138 \pm 32.9[10]^{\mathrm{b}}\end{array}$ & 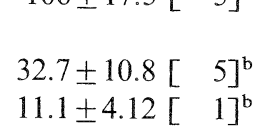 \\
\hline $\begin{array}{l}\text { Subcutaneous } \\
\text { (ng/g) }\end{array}$ & $551 \pm 104[100]^{\mathrm{a}}$ & $96.2 \pm 14.1[17]^{\mathrm{b}}$ & $30.0 \pm 10.2[5]^{\mathrm{b}}$ \\
\hline
\end{tabular}

Mean \pm SE for $5-6$ rats. Values with different superscripts in the same line are significantly different from one another $(p<0.05)$. Numbers within brackets indicate $\%$ of ad libitum values.

Table 5. PCP concentration in the blood through time.

\begin{tabular}{cccc}
\hline & \multicolumn{3}{c}{ PCP in blood $(\mathrm{ng} / \mathrm{ml})$} \\
\cline { 2 - 4 } Time & Ad libitum & $25 \%$ restricted diet & $50 \%$ restricted diet \\
\hline Day 1 & $1,087 \pm 192[100]^{\mathrm{a}}$ & $1,223 \pm 267[110]^{\mathrm{a}}$ & $2,813 \pm 222[253]^{\mathrm{b}}$ \\
Day 2 & $911 \pm 63.9[100]^{\mathrm{a}}$ & $1,528 \pm 90.6[168]^{\mathrm{b}}$ & $2,413 \pm 71,8[265]^{\mathrm{c}}$ \\
Day 4 & $61.4 \pm 8.33[100]^{\mathrm{a}}$ & $275 \pm 87.7[448]^{\mathrm{b}}$ & $164 \pm 31.8[267]^{\mathrm{b}}$ \\
\hline
\end{tabular}

Mean \pm SE for 5-6 rats. Values with different superscripts in the same line are significantly different from one another $(p<0.05)$. Numbers within brackets indicate $\%$ of ad libitum values.

A major metabolite of PECB in the liver is PCP, which has also been detected in blood (16). PCP detected in blood during days 1-4 of the restricted diet groups was significantly higher in concentration than that in the AD group (Table 5). Furthermore, levels of urinary PCP, which is one of the PECB metabolites found in urine, were also higher up to day 3 in the restricted diet groups (Table 6).

Table 7 shows the changes of hepatic drug-metabolizing enzyme activity following RF and PECB administration. RF did not affect cytochrome P-450 content and UDP-glucuronyltransferase activity, but decreased glutathione $S$-transferase 
Table 6. PCP excretion in urine through time.

\begin{tabular}{rccc}
\hline \multirow{3}{*}{$\begin{array}{c}\text { Time } \\
\text { (day) }\end{array}$} & \multicolumn{3}{c}{ PCP in urine $(\mu \mathrm{g})$} \\
\cline { 2 - 4 } & Ad libitum & $25 \%$ restricted diet & $50 \%$ restricted diet \\
\hline $0-1$ & $52.1 \pm 4.71[100]^{\mathrm{a}}$ & $47.5 \pm 5.62[91]^{\mathrm{a}}$ & $70.8 \pm 5.77[136]^{\mathrm{b}}$ \\
$1-2$ & $66.8 \pm 8.71[100]^{\mathrm{a}}$ & $93.5 \pm 9.92[140]^{\mathrm{a}}$ & $137 \pm 9.96[206]^{\mathrm{b}}$ \\
$2-3$ & $56.9 \pm 5.13[100]$ & $70.1 \pm 12.5[123]$ & $79.8 \pm 10.9[140]$ \\
$3-4$ & $38.3 \pm 7.25[100]$ & $37.6 \pm 8.36[98]$ & $34.8 \pm 3.88[91]$ \\
$4-8$ & $32.3 \pm 4.88[100]$ & $27.9 \pm 6.61[86]$ & $22.1 \pm 2.03[69]$ \\
Total & $246 \pm 18.9[100]^{\mathrm{a}}$ & $277 \pm 17.1[114]^{\mathrm{a}}$ & $345 \pm 18.9[141]^{\mathrm{b}}$ \\
$0-8$ & & &
\end{tabular}

Mean \pm SE for 5-6 rats. Values with different superscripts in the same line are significantly different from one another $(p<0.05)$. Number within brackets indicate $\%$ of ad libitum values.

Table 7. The activity of drug-metabolizing enzymes in the liver.

\begin{tabular}{|c|c|c|c|}
\hline & Ad libitum & $25 \%$ restricted diet & $50 \%$ restricted diet \\
\hline \multicolumn{4}{|l|}{ Untreated control } \\
\hline P450 content ${ }^{1}$ & $1.17 \pm 0.072[100]$ & $1.11 \pm 0.045[95]$ & $1.16 \pm 0.049[99]$ \\
\hline 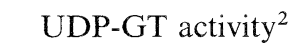 & $6.22 \pm 0.162[100]$ & $6.74 \pm 0.520[108]$ & $6.88 \pm 0.241[111]$ \\
\hline GSH-ST activity ${ }^{3}$ & $614 \pm 26.9 \quad[100]^{\mathrm{a}}$ & $511 \pm 29.6[83]^{\mathrm{b}}$ & $417 \pm 28.5[68]^{\mathrm{c}}$ \\
\hline \multicolumn{4}{|l|}{ PECB-treated } \\
\hline P450 content ${ }^{1}$ & $1.20 \pm 0.094[103]$ & $1.24 \pm 0.079[106]$ & $1.01 \pm 0.041[88]$ \\
\hline 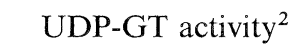 & $5.89 \pm 0.251[95]^{\mathrm{a}}$ & $6.43 \pm 0.328[103]^{\mathrm{ab}}$ & $7.68 \pm 0.595[123]^{\mathrm{b}}$ \\
\hline GSH-ST activity ${ }^{3}$ & $553 \pm 24.5 \quad[90]^{\mathrm{a}}$ & $476 \pm 14.4[78]^{\mathrm{b}}$ & $517 \pm 15.5[82]^{\mathrm{ab}, *}$ \\
\hline
\end{tabular}

Mean \pm SE for 5-6 rats. Values with different superscripts in the same line are significantly different from one another $(p>0.05)$. ${ }^{*}$ Statistically different from untreated control. Numbers within brackets indicate $\%$ of ad libitum (control) values. ${ }^{1}$ Cytochrome P-450 (nmol/mg protein). ${ }^{2}$ UDP-glucuronyltransferase $(\mathrm{nmol} / \mathrm{mg}$ protein $/ 20 \mathrm{~min}) .{ }^{3}$ Glutathione $S$-transferase ( $\mathrm{nmol} / \mathrm{mg}$ protein $/ \mathrm{min}$ ).

activity. PECB administration did not have any influence on these enzymes except for glutathione $S$-transferase, whose activity was significantly increased. The content of hepatic GSH, a reduced form of glutathione, in the restricted diet groups was significantly increased compared with that in the AD groups. PECB administration decreased GSH and increased GSSG, an oxidized form of glutathione, only in the livers from the AD group. As a result, the ratio of GSH/GSSG was significantly lower in the $\mathrm{AD}$ group than that in the restricted diet groups following PECB administration (Table 8). 
Table 8. Liver glutathione levels.

\begin{tabular}{ccll}
\hline & \multicolumn{1}{c}{ Ad libitum } & $25 \%$ restricted diet & $50 \%$ restricted diet \\
\hline Untreated control & & & \\
GSH $(\mu \mathrm{mol} / \mathrm{g})$ & $5.62 \pm 0.124[100]^{\mathrm{a}}$ & $6.03 \pm 0.165[107]^{\mathrm{b}}$ & $6.05 \pm 0.093[108]^{\mathrm{b}}$ \\
GSSG $(\mu \mathrm{mol} / \mathrm{g})$ & $0.728 \pm 0.035[100]$ & $0.740 \pm 0.030[102]$ & $0.728 \pm 0.019[100]$ \\
GSH $/ \mathrm{GSSG}$ & $7.78 \pm 0.301[100]$ & $8.20 \pm 0.405[105]$ & $8.33 \pm 0.137[107]$ \\
PECB-treated & & & \\
GSH $(\mu \mathrm{mol} / \mathrm{g})$ & $4.02 \pm 0.321[72]^{\mathrm{a}}$ & $6.71 \pm 0.455[119]^{\mathrm{b}}$ & $6.43 \pm 0.161[114]^{\mathrm{b}}$ \\
GSSG $(\mu \mathrm{mol} / \mathrm{g})$ & $1.000 \pm 0.067[137]^{\mathrm{a}, *}$ & $0.803 \pm 0.037[110]^{\mathrm{b}}$ & $0.759 \pm 0.022[104]^{\mathrm{b}}$ \\
GSH $/ \mathrm{GSSG}$ & $4.07 \pm 0.318[52]^{\mathrm{a}, *}$ & $8.40 \pm 0.554[108]^{\mathrm{b}}$ & $8.49 \pm 0.214[109]^{\mathrm{b}}$ \\
\hline
\end{tabular}

Mean \pm SE for 5-6 rats. Values with different superscripts in the same line are significantly different from one another $(p<0.05)$. ${ }^{*}$ Statistically different from untreated control. Numbers within brackets indicate $\%$ of ad libitum values of the untreated control.

\section{DISCUSSION}

In this experiment we used PECB as a lipophilic chemical and examined the influence of RF on the absorption, metabolism, and accumulation of PECB in rats. As described in the results, although RF increased PECB absorption, it also enhanced PECB metabolism and markedly decreased PECB residue in the liver, kidney, brain, and various fat tissues.

The fecal excretion pattern of PECB could be divided into two phases with regard to its time course: the excretion of unabsorbed PECB during days 0-2, and the excretion of absorbed PECB during days 3-8. As shown in Table 2, the reduction of food by 25 and $50 \%$ from that of the $\mathrm{AD}$ group markedly decreased PECB excretion in both phases. The decreased fecal excretion of PECB in the first phase indicated an ehanced absorption of PECB. The results are consistent with those reported by Villeneuve(5), who observed that the fecal excretion of hexachlorobenzene administered at the dose of $1 \mathrm{mg} / \mathrm{kg}$ to rats was decreased by RF. In contrast, an increase of the fecal excretion of $2,2^{\prime}, 4,4^{\prime}, 5,5^{\prime}$-hexachlorobiphenyl (HCB) by rats on RF was reported by Wyss et al. (7) and Jondorf et al. (8). In their studies, they used a radioactive chemical and measured the radioactivity in the fecal excretion which reflected the presence of both the parent chemical and its metabolites. Although we did not examine the fecal excretion of PECB metabolites, the enhancement of its excretion by RF may likely to have occurred. The RF-influenced decrease in the fecal excretion of PECB was inconsistent with the decrease in the PECB residue in various tissues (Table 4). However, this discrepancy might be explained by the high absorption rate of PECB, which might obscure the differences in the fecal excretion of PECB among the AD and the restricted diet groups. As described in the RESUlTs section, the total amount of PECB excreted into feces was less than a mere $4-5 \%$ of the dose in any of the $\mathrm{AD}$ or restricted diet groups. 
Enhanced PECB metabolism due to RF was indicated by a relatively short biological half-life of PECB in the blood, and high concentrations of PCP in the blood and urine. This enhanced metabolism might have reduced the level of PECB residues in various tissues. There might be at least two possibilities involved in the enhanced PECB metabolism in the restricted diet groups. One is an increase in the activity of hepatic drug-metabolizing enzymes, and the other is change of the hepatic PECB concentration as a substrate of the enzymes.

PECB accumulated in fat tissue because of its lipophilic properties, whereas PCP could not be detected in fat tissues (18). Therefore, the transformation of PECB to PCP by cytochrome P-450 seems to be an important step in the excretion of PECB accumulated in the body. It has been observed that RF in male rats increase both hepatic cytochrome P-450 content $(1,2)$ and hepatic monooxygenase activity which correspond with the increase of specific isoforms of cytochrome P-450s: IIC1, IIE1, IIIA1, and IVI (19). It has also been suggested that PECB treatment in rats induces cytochrome P-450 IIIA1 which is induced by dexamethazone treatment (20). In the present experiment, we only examined total content of cytochrome P-450 in the liver. Therefore, it is unclear whether RF significantly induced the cytochrome P-450 which is specific for PECB metabolism. However, no significant change of the total content of cytochrome P-450 was observed to have been brought about by RF as shown in Table 7. This may be due to the short period of RF treatment. No increase of the cytochrome P-450 content and the small changes of conjugated enzyme activities (Table 7) may indicate that the enhanced metabolism of PECB in the restricted diet groups was not likely to be due to the changes in the activity of the hepatic drug metabolizing enzymes per se. Further study will need to clearify how the changes of hepatic drug-metabolizing enzymes contribute to the RF-influenced increase in PECB metabolism.

As shown in Table 1, RF markedly reduced the fat tissue mass in which a large amount of PECB is accumulated without metabolic transformation. The decrease in fat tissue mass reduces its capacity to store PECB there, increases PECB concentrations in the blood and liver, and thus accelerates PECB metabolism by the hepatic drug-metabolizing enzymes. This is supported by the facts that blood concentrations of PECB on days 1-2 and PCP on days 1-4 in the restricted diet groups were significantly higher than those in the AD group (Tables 3 and 5), and that the biological half-life of PECB in rats was approximately one day (18). These phenomena were quite similar to those observed in an experiment using young and adult rats (9). In young rats, the fat tissue mass was smaller and the activity of hepatic drug-metabolizing enzymes was lower when compared to adult rats. After the administration of PECB, the metabolism of PECB in young rats was at a much higher rate than that in adult rats: the biological half-life of PECB in the blood was $10.6 \mathrm{~h}$ in young rats and $42.9 \mathrm{~h}$ in adult rats. In that experiment, the changes in PECB and PCP concentrations in the blood were similar to those found in the present experiment. Birnbaum (21) has pointed out that the decrease in the clearance of hexachlorobiphenyl from the systems of older animals was related to the increase 
of fat tissue mass with aging. Decad et al. (22) have examined the distribution and excretion of 2,3,7,8-tetrachlorodibenzofuran (TCDF) in two inbred strains of mice with differences in adipose tissue mass, and have demonstrated that the half-life of TCDF in adipose tissue and in the whole body was shorter and the concentration of TCDF in the liver was constantly higher in mice having a smaller adipose tissue mass. Their report also suggested that a small fat tissue mass increased the concentration of TCDF in the liver by limiting its distribution to fat tissue, and accelerated TCDF metabolism by hepatic drug-metabolizing enzymes.

Effects of fasting or RF on the excretion of lipophilic chemicals such as DDT, $\mathrm{BHC}$, hexachlorobenzene accumulated in the body have been tested. In the cases of hexachlorobenzene (5), and DDT (3), such treatments increased their toxicity by promoting the redistribution of the chemicals from fat tissue to the other target organs, especially the brain. In our present study, no such redistribution of PECB was observed. This seems to be related to the metabolizable nature of PECB compared with that of DDT and hexachlorobenzene. Interestingly, Oshiba and Kawakita (23) have reported that fasting decreased the body burden of $\gamma$-BHC, an easily metabolized isomer, whereas the same treatment led to the redistribution of $\beta$ - $\mathrm{BHC}$, an unmetabolizable isomer, from fat tissue to the brain, thus enhancing the toxicity of the chemical. A similar finding has also been reported by Birnbaum(21), who observed that in the case of hexachlorobiphenyl, the metabolizable isomer, 2,3,6-hexachlorobiphenyl, was rapidly excreted without being redistributed, but the unmetabolizable isomer, 2,4,5-hexachlorobiphenyl, was redistributed in several tissues.

In the present experiment, $15 \mathrm{mg}$ of PECB was administered per rat. Therefore, the calculated doses (per $\mathrm{kg}$ body weight) were $85 \mathrm{mg} / \mathrm{kg}$ in the AD group, 100 and $125 \mathrm{mg} / \mathrm{kg}$ in the 25 and $50 \%$ restricted diet groups, respectively, indicating that the higher the RF level was, the higher the dose was per $\mathrm{kg}$ body weight. In addition, the enhanced metabolism of PECB by RF might lead to the production of a large amount of active metabolites. These points suggest that RF should enhance the toxicity of PECB. We have not clarified the effect of RF on the toxicity of PECB in the present experiment. However, we observed that with $\mathrm{PECB}$ administration to the AD groups, a reduced form of glutathione (GSH) decreased and an oxidized form of glutathione (GSSG) increased in the liver. This did not occur in the restricted diet groups (Table 8). This difference may be explained by the high residue of PECB in the AD group at the time of sacrifice. Den Besten et al. $(20,24)$ have reported that PECB is metabolized to PCP and then to hydroquinones which covalently bind to protein and DNA, and that GSH has a protective effect on the covalent binding. Therefore, the continued high levels of hepatic GSH in the restricted diet groups even after PECB has been administered (Table 8) may help to reduce the toxicity of the PECB metabolites.

In conclusion, the present report suggests that fat tissue has an important role to play in how lipophilic chemicals are handled in the body. Fat tissue provides not only the site at which they accumulate, but also influences the hepatic 
concentration of these chemicals available to the drug-metabolizing enzymes, and thus their metabolism as well.

This work was financially supported by Environment Agency of Japan.

\section{REFERENCES}

1) Sachan, D. S. (1982): Modulation of drug metabolism by food restriction in male rats. Biochem. Biophys. Res. Commun., 104 984-989.

2) Hashimi, R. S., Siddiqui, A. M., Kachole, M. S., and Pawar, S. S. (1986): Alterations in hepatic microsomal mixed-function oxidase system during different levels of food restriction in adult male and female rats. J. Nutr., 116, 682-688.

3) Ecobichon, D. J., and Saschenbrecker, P. W. (1969): The redistribution of stored DDT in cockerels under the influence of food deprivation. Toxicol. Appl. Pharmacol., 15, $420-432$.

4) Mitjavila, S., Carrera, G., and Fernandez, Y. (1981): Evaluation of the toxic risk of accumulated DDT in the rat: during fat mobilization. Arch. Environ. Contam. Toxicol., 10, 471-481.

5) Villeneuve, D. C. (1975): The effect of food restriction on the redistribution of hexachlorobenzene in the rat. Toxicol. Appl. Pharmacol., 31, 313-319.

6) Polin, D., Olson, B., Bursian, S., and Lehning, E. (1986): Enhanced withdrawal from chickens of hexachlorobenzene (HCB) and pentachlorophenol (PCP) by colestipol, mineral oil, and/or restricted feeding. J. Toxicol. Environ. Health, 19, 359-368.

7) Wyss, P. A., Mühlebach, S., and Bickel, M. H. (1982): Pharmacokinetics of $2,2^{\prime}, 4,4^{\prime}, 5,5^{\prime}$-hexachlorobiphenyl $(6-\mathrm{CB})$ in rats with decreasing adipose tissue mass. I. Effects of restricted food intake two weeks after ádministration of 6-CB. Drug Metab. Dispos., 10, 657-661.

8) Jondorf, W. R., Wyss, P. A. Mühlebach, S., and Bickel, M. H. (1983): Disposition of $2,2^{\prime}, 4,4^{\prime}, 5,5^{\prime}$-hexachlorobiphenyl (6-CB) in rats with decreasing adipose tissue mass. II. Effects of restricting food intake before and after 6-CB administration. Drug Metab. Dispos., 11, 597-601.

9) Umegaki, K., and Ichikawa, T. (1990): Involvement of adipose tissue in metabolism and in accumulation of pentachlorobenzene in rats: Comparison with young and adult rats. Shokuhin Eiseigaku Zassi (J. Food Hyg. Soc. Jpn.), 31, 485-490.

10) Umegaki, K., and Ichikawa, T. (1988): Relationship between changes of drug metabolizing enzyme activities and toxicity following pentachlorobenzene administration in rats. Eisei Kagaku (in Japanese), 34, 518-523.

11) Omura, T., and Sato, R. (1964): The carbon monooxide-binding pigment of liver microsomes. J. Biol. Chem., 239, 2370-2378.

12) Dutton, G. J., Leakey, J. E. A., and Pollard, M. R. (1981): Assays for UDP-glucuronyltransferase activities. Methods Enzymol., 77, 383-391.

13) Habig, W. H., and Jakoby, W. B. (1981): Assays for differentiation of glutathione S-transferases. Methods Enzymol., 77, 398-405.

14) Lowry, O. H., Rosebrough, N. J., Farr, A. L., and Randall, R. J. (1951): Protein measurement with the Folin phenol reagent. J. Biol. Chem., 193, 265-275.

15) Mokrasch, L. C., and Teschke, E. J. (1984): Glutathione content of cultured cells and rodent brain regions: a specific fluorometric assay. Anal. Biochem., 140, 506-509.

16) Umegaki, K., Yamaguchi, T., and Ichikawa, T. (1989): Distribution of penta- 
chlorobenzene and its metabolite in rats. Eisei Kagaku (in Japanese), 35, 360-364.

17) Umegaki, K., and Ichikawa, T. (1990): Influences of food restriction on metabolism and accumulation of pentachlorobenzene and on hepatic drug-matabolizing enzymes in rats. Shokuhin Eiseigaku Zassi (J. Food Hyg. Soc. Jpn.), 31, 227-232.

18) Umegaki, K., and Ichikawa, T. (1989): Effects of cholesterol feeding on the distribution, metabolism and accumulation of pentachlorobenzene in rats. J. Nutr. Sci. Vitaminol., 35, 291-301.

19) Leakey, J. E. A., Cunny, H. C., Bazare, J., Jr., Webb, P. J., Feuers, R. J., Duffy, D. H., and Hart, R. W. (1989): Effects of aging and caloric restriction on hepatic drug metabolizing enzymes in the fischer 344 rat. I: the cytochrome P-450 dependent monoxygenase system. Mech. Ageing Dev., 48, 145-155.

20) Den Besten, C., Smink, M. C. C., Den Vries, E. J., and Van Bladeren, P. J. (1991): Metabolic activation of 1,2,4-trichlorobenzene and pentachlorobenzene by rat liver microsomes: a major role for quinone metabolites. Toxicol. Appl. Pharmacol., 108, 223-233.

21) Birnbaum, L. S. (1983): Distribution and excretion of 2,3,6, $2^{\prime}, 3^{\prime}, 6^{\prime}-$ and $2,4,5,2^{\prime}, 4^{\prime}, 5^{\prime}-$ hexachlorobiphenyl in senescent rats. Toxicol. Appl. Pharmacol., 70, 262-272.

22) Decad, G. M., Birnbaum, L. S., and Matthews, H. B. (1981): Distribution and excretion of 2,3,7,8-tetrachlorodibenzofuran in C57BL/6J and DBA/2J mice. Toxicol. Appl. Pharmacol., 59, 564-573.

23) Oshiba, K., and Kawakita, K. (1972): Interaction between toxicant and nutrition (IV), effect of lipid metabolism on residue of the BHC deposition in rat tissues. Shokuhin Eiseigaku Zassi (J. Food Hyg. Soc. Jpn.), 13, 189-194.

24) Den Besten, C., Peters, M. M. C. G., and Van Bladeren, P. J. (1989): The metabolism of pentachlorobenzene by rat liver microsomes: the nature of the reactive intermediates formed. Biochem. Biophys. Res. Commun., 163, 1275-1281. 